\title{
PENINGKATAN PROFESIONALISASI \\ MELALUI PERTUKARAN GURU
}

\section{Firman Firman \\ Jurusan Bimbingan dan Konseling FIP UNP \\ Email : firman@konselor.org}

\section{A. Pendahuluan}

Kemerosotan kualitas pendidikan di Indonesia sudah bertahun-tahun dialami pemerintah dan masyarakat. Kondisi ini ditunjukkan berkali-kalinya kurikulum dituding sebagai penyebab kemerosotan kualitas pendidikan tersebut. Hal ini tercermin dengan adanya upaya mengubah kurikulum mulai kurikulum 1975 diganti dengan kurikulum 1984, kemudian diganti lagi dengan kurikulum 1994 dan seterusnya.

Bekaitan dengan hal itu, Nasanius (1998) menjelaskan kemerosotan pendidikan bukan diakibatkan oleh kurikulum tetapi disebabkan oleh kurangnya kemampuan profesionalisme guru dan keengganan siswa belajar. Profesionalisme sebagai penunjang kelancaran guru dalam melaksanakan tugasnya, sangat dipengaruhi oleh : faktor internal, yang meliputi minat dan bakat serta faktor eksternal, berkaitan dengan lingkungan sekitar, sarana prasarana, serta berbagai latihan yang diterima guru (Sumargi, 1996). Profesionalisme guru dan tenaga kependidikan masih belum memadai, terutama dalam penguasaan keilmuannya.

Dari segi kuantitatif jumlah tenaga pendidik sudah cukup banyak, tetapi mutu dan profesionalisme belum sesuai dengan harapan. Banyak diantara mereka yang tidak berkualitas dalam menyampaikan materi pelajaran 
kepada siswa. Tidak jarang materi yang disampaikan keliru dan mereka kurang mampu menyajikan serta menyelenggarakan pendidikan berkualitas (Dahrin,2000).

Di Era globalisasi telah memunculkan kesadaran masyarakat pada tingkat global bahwa dunia merupakan satu kesatuan. Interaksi dan saling ketergantungan antar individu/masyarakat/negara semakin diperlukan dalam berbagai aspek kehidupan. Semua negara harus bekerja sebagai mitra untuk memajukan perdamaian dan kesejahteraan, serta menanggulangi masalahmasalah internasional. Salah satu cara yang paling pasti untuk mengembangkan dan memperkokoh keprofesionalisasian guru adalah melalui pertukaran guru antar negara. Melalui program pertukaran akan memungkinkan guru mempelajari bahasa, mengalami kebudayaan lain, mengembangkan pengertian yang lebih luas mengenai soal-soal global, serta membina persahabatan yang langgeng dengan rekan seprofesi di negaranegara lain yang pada suatu saat akan ditransfer kepada anak didik untuk pelaksanaan pembangunan politik, budaya, dan ekonomi negara masingmasing.

Pertukaran budaya dan pengalaman antar guru dari berbagai negara memungkinkan pendidikan sebagai pelopor pembaharuan dapat diwujud. Pengembangan pengetahuan dan pengalaman guru dari berbagai negara merupakan salah satu prioritas yang seharusnya dikembangkan dalam proses pendidikan, yang selanjutnya akan mengembangkan proses dan hasil belajar. Sehubungan dengan hal itu, guru diharapkan berperan dalam pengembangan 
kurikulum pendidikan yang dapat memberikan pengalaman-pengalaman merangsang perkembangan kreativitas, intelektualitas, dan sosial. Kurikulum harus menyajikan hal-hal yang praktis dan disesuaikan dengan latar belakang kehidupan yang bervariasi, tujuan hidup, serta daya pemahaman terhadap persoalan yang berbeda.

Guru diharapkan dapat menyajikan kesempatan-kesempatan untuk berbuat dan bertindak berdasarkan apa yang dipahami seseorang maupun kesempatan untuk berteori tentang solusi yang ideal dari berbagai masalah. Dengan kata lain, kurikulum harus dapat diperkenalkan kepada anak didik dengan berbagai cara belajar maupun berbagai jenis pengetahuan. Pada gilirannya hal-hal ini mampu mempersiapkan anak didik untuk merencanakan masa depan serta berperan aktif dalam merealisasikannya di lingkungan masyarakat.

\section{B. Profesionalisasi Guru}

Profesionalisme menekankan kepada penguasaan ilmu pengetahuan, kemampuan manajemen beserta strategi penerapannya. Maister (1997) mengemukakan profesionalisme bukan sekadar pengetahuan teknologi dan manajemen tetapi lebih merupakan sikap, pengembangan profesionalisme lebih dari seorang teknisi bukan hanya memiliki keterampilan yang tinggi tetapi memiliki suatu tingkah laku yang dipersyaratkan untuk itu.

Standar profesionalisasi guru di Indonesia jauh berbeda dengan kondisi di negara maju lainnya. Stiles dan Horsley (1998) dan NRC (1996) 
mengungkapkan ada empat standar pengembangan profesi guru, yaitu; (1) standar pengembangan profesi A adalah pengembangan profesi untuk para guru sains, yang memerlukan pembelajaran isi sains yang diperlukan melalui perspektif-perspektif dan metode-metode inquiri. Para guru dalam sketsa ini melalui sebuah proses observasi fenomena alam, membuat penjelasanpenjelasan dan menguji penjelasan-penjelasan tersebut berdasarkan fenomena alam; (2) standar pengembangan profesi $\mathrm{B}$ adalah pengembangan profesi untuk guru sains memerlukan pengintegrasian pengetahuan sains, pembelajaran, pendidikan, dan siswa, juga menerapkan pengetahuan tersebut ke pengajaran sains. Pada guru yang efektif tidak hanya tahu sains namun mereka juga tahu bagaimana mengajarkannya. Guru yang efektif dapat memahami bagaimana siswa mempelajari konsep-konsep yang penting, konsep-konsep apa yang mampu dipahami siswa pada tahap-tahap pengembangan, profesi yang berbeda, dan pengalaman, (3) standar pengembangan profesi $\mathrm{C}$ adalah pengembangan profesi untuk para guru sains memerlukan pembentukan pemahaman dan kemampuan untuk pembelajaran sepanjang masa. Guru yang baik biasanya tahu bahwa dengan memilih profesi guru, mereka telah berkomitmen untuk belajar sepanjang masa. Pengetahuan baru selalu dihasilkan sehingga guru berkesempatan terus untuk belajar; (4) standar pengembangan profesi $\mathrm{D}$ adalah program-program profesi untuk guru sains harus koheren (berkaitan) dan terpadu. Standar ini dimaksudkan untuk menangkal kecenderungan kesempatan-kesempatan pengembangan profesi terfragmentasi. 
Selanjutnya, Tilaar, (1999.2:284), menggambarkan profesi guru pada abad 21 dihadapkan pada tiga karakteistik masyarakat yaitu. (1) masyarakat teknologi, (2) masyarakat terbuka, dan (3) masyarakat madani. Adapun proses pendidikan dan penyelenggaraan pendidikan di masa itu akan berhadapan dengan suasana interaktif antara peserta didik dengan pendidik. Masyarakat teknologi, dan masyarakat terbuka hanya mau menerima para pelaku profesional dalam melayani setiap kebutuhan masyarakat, sedangkan masyarakat madani hanya dapat dibentuk melalui proses pendidikan yang diselenggarakan secara profesional.

Apabila guru di Indonesia telah memenuhi standar profesionalisasi guru seperti tersebut di atas, maka kualitas Sumber Daya Manusia Indonesia semakin baik. Selain memiliki standar profesional guru sebagaimana uraian di atas, Selanjutnya Supriadi (1998) menjelaskan untuk menjadi profesional seorang guru dituntut untuk memiliki: (1) guru mempunyai komitmen pada siswa dan proses belajarnya, (2) guru menguasai secara mendalam bahan/mata pelajaran yang diajarkannya serta cara mengajarnya kepada siswa, (3) guru bertanggung jawab memantau hasil belajar siswa melalui berbagai cara evaluasi, (4) guru mampu berfikir sistematis tentang apa yang dilakukannya dan belajar dari pengalamannya, (5) guru seyogyanya merupakan bagian dari masyarakat belajar dalam lingkungan profesinya.

Sehubungan dengan uraian tersbeut, Arifin (2000) menjelaskan guru Indonesia yang profesional dipersyaratkan mempunyai; (1) dasar ilmu yang kuat sebagai pengejawantahan terhadap masyarakat teknologi dan masyarakat 
ilmu pengetahuan di abad 21; (2) penguasaan kiat-kiat profesi berdasarkan riset dan praksis pendidikan yaitu ilmu pendidikan sebagai ilmu praksis bukan hanya merupakan konsep-konsep belaka. Pendidikan merupakan proses yang terjadi di lapangan dan bersifat ilmiah, serta riset pendidikan hendaknya diarahkan pada praksis pendidikan masyarakat Indonesia; (3) pengembangan kemampuan profesional berkesinambungan, profesi guru merupakan profesi yang berkembang terus menerus dan berkesinambungan antara LPTK dengan praktek pendidikan.

Kurang berkembangnya profesi guru dan ilmu pendidikan di Indonesia secara baik, salah satu hal disebabkan oleh terputusnya program pre-service dan in-service, pertimbangan birokratis yang kaku atau manajemen pendidikan yang lemah. Sehubungan dengan hal itu, diperlukan paradigma baru melahirkan profil guru Indonesia yang profesional, diantaranya : (1) memiliki kematangan kepribadian sebagai guu; (2) penguasaan ilmu pengetahuan dan teknologi yang mantap; (3) kemampuan mendorong belajar sepanjang hayar; dan (4) kemauan menggembangan profesi secara berkelanjutan.

Semiawan (1991) menjelaskan pemenuhan persyaratan guru profesional akan mengubah peran guru yang semula sebagai orator yang verbalistis menjadi berkekuatan dinamis dalam menciptakan suatu suasana dan lingkungan belajar yang invitation learning environment. Selanjutnya Soewondo (Arifin 2000) menjelaskan dalam peningkatan mutu pendidikan, guru memiliki multi fungsi yaitu sebagai fasilitator, motivator, informator, 
komunikator, transformator, change agent, inovator, konselor, evaluator, dan administrator.

Berkaitan dengan hal itu, Akadum (1999) menjelaskan penyebab rendahnya profesionalisme guru, adalah (1) masih banyak guru yang tidak menekuni profesinya secara total, (2) rendahnya kepatuhan guru terhadap norma dan etika profesi keguruan, (3) pengakuan terhadap ilmu pendidikan dan keguruan masih setengah hati dari pengambilan kebijakan dan pihakpihak terlibat. Hal ini terbukti dari masih belum mantapnya kelembagaan pencetak tenaga keguruan dan kependidikan, (4) masih belum smooth-nya perbedaan pendapat tentang proporsi materi ajar yang diberikan kepada calon guru, (5) masih belum berfungsi PGRI sebagai organisasi profesi yang berupaya secara maksimal meningkatkan profesionalisme anggotanya.

Pengembangan profesi guru dijamin pemerintah dalam UndangUndang Sisdiknas Nomor 20 Tahun 2003, Bab XI, diantaranya mengatur tentang Hak dan Kewajiban, penyelenggaraan pendidikan yang bermutu, kualifikasi, sertifikasi, dan akreditasi pendidik. Pasar 39 ayat (2) ditegaskan bahwa pendidik merupakan tenaga profesional yang bertugas merencanakan, dan melaksanakan proses pembelajaran, menilai hasil pembelajaran, melakukan pembimbingan dan pelatihan, serta melakukan penelitian dan pengabdian kepada masyarakat, terutama pendidik pada perguruan tinggi. Pendidik yang dimaksud menurut UU Sisdiknas Nomor 20 Tahun 2003 (Pasal 1 ayat 6) adalah tenaga kependidikan yang berkualifikasi sebagai guru, dosen, konselor, pamong belajar, widyaiswara, tutor, instruktur, fasilitator, dan 
sebutan lain yang sesuai dengan kekhususannya, serta berpartisipasi dalam menyelenggarakan pendidikan. Sosok guru dan tenaga kependidikan yang digambarkan dalam Undang-Undang tertinggi dalam bidang pendidikan itu menuntut pengetahuan dan keterampilan yang tinggi agar supaya hasil karya guru menunjukkan hasil kerja yang berkualitas, unggul, dan dapat dipercaya dengan demikian akan dihargai oleh stakehorders, dengan sendirinya profesi guru dan tenaga kependidikan akan diterima sebagai hasil kerja yang profesional.

Seiring dengan perubahan sosial dan budaya kinerja guru juga terus menerus dikaji dan disempurnakan, tidak dikenal adanya pekerjaan rutinitas dalam pekerjaan yang bersifat profesional. Pada dasarnya pekerjaan profesional mengutamakan layanan prima terhadap stakehorders atas dasar kemampuan menerapkan pengetahuan dan keahlian serta keterampilannya, dan stakeholders merasakan manfaatnya sehingga diakui dan dihargai hasil pekerjaan tersebut. Dari jasa-jasa yang diberikan oleh profesi guru dan tenaga kependidikan tentunya masyarakat mengharapkan bahwa profesi guru dapat memberikan jasanya yaitu mencerdaskan generasi muda agar generasi tersebut dapat meningkatkan taraf hidup yang lebih sejahtera dalam menyongsong hari depannya.

Pengembangan landasan pengetahuan yang kuat pada diri guru dan tenaga kependidikan dapat dilakukan dengan cara mengikuti programprogram pendidikan dan pelatihan bisa melalui studi lanjutan, atau program intensif yang dilakukan dalam pendidikan profesi atau sertifikasi. 
Pengetahuan praktis dapat diperoleh melalui seminar-seminar nasional yang membahas kasus-kasus yang terjadi diberbagai masyarakat yang beraneka ragam atau melalui sosialisasi yang ditulis dalam jurnal-jurnal keprofesian. Sedangkan untuk menumbuhkembangkan tehnik kerja yang mapan dapat diperoleh melalui pengalaman-pengalaman pribadi melalui ujicoba (eksperimen) dan penelitian-penelitian yang dilakukan. Dengan melaksanakan keemapat ciri tersebut diharapkan akan menumbuhkan rasa tanggung jawab yang tinggi sebagai seorang guru dan tenaga kependidikan yang profesional.

Pemerintah telah berupaya meningkatkan profesionalisme guru, diantaranya meningkatkan kualifikasi dan persyaratan jenjang pendidikan yang lebih tinggi bagi tenaga pengajar mulai tingkat persekolahan sampai perguruan tinggi. Program penyetaaan Diploma II bagi guru-guru SD, Diploma III bagi guru-guru SLTP dan Strata I (sarjana) bagi guru-guru SLTA. Selain diadakannya penyetaraan guru-guru, upaya lain yang dilakukan pemerintah adalah program sertifikasi. Program sertifikasi telah dilakukan oleh Direktorat Pembinaan Perguruan Tinggi Agama Islam (Dit Binrua) melalui proyek Peningkatan Mutu Pendidikan Dasar (ADB Loan 1442-INO) yang telah melatih 805 guru MI dan 2.646 guru MTs dari 15 Kabupaten dalam 6 wilayah propinsi yaitu Lampung, Jawa Barat, Jawa Tengah, Jawa Timur, NTB dan Kalimantan Selatan (Pantiwati, 2001).

Selain sertifikasi upaya lain yang telah dilakukan di Indonesia untuk meningkatkan profesionalisme guru, misalnya PKG (Pusat Kegiatan Guru, dan KKG (Kelompok Kerja Guru) yang memungkinkan para guru untuk 
berbagi pengalaman dalam memecahkan masalah-masalah yang mereka hadapi dalam kegiatan mengajarnya (Supriadi, 1998). Profesionalisasi harus dipandang sebagai proses yang terus menerus.

Selain upaya tersebut di atas, program pertukaran guru antar sekolah, daerah dan negera tidak kalah penting dalam upaya peningkatan profesionalisasi. Berbagai kemajuan yang telah diperoleh di sekolah, daerah, atau negara asal dan yang didatanggi akan dikombinasikan untuk mengejar kualitas yang diharapkan dan begitu pula sebaliknya.

\section{Peranan Pertukaran Guru dalam Peningkatan Profesionalisasi}

Program pertukaran guru ditujukan untuk memberikan latihan pengembangan profesi bagi guru dari kedua sekolah/daerah atau negara, memperbaiki keterampilan berbahasa, memperkenalkan kepada mereka ideide yang membangkitkan semangat dan pengalaman hidup di kedua seekolah/daerah atau negara, serta mendorong hubungan yang langgeng secara pribadi maupun institusi.

Guru yang diberi kesempatan untuk melaksanakan pertukaran dengan guru lainnya yang berada di Sekolah/daerah atau negara yang ditinggalkan adalah memiliki prestasi dibandingkan guru lainnya. Selama mereka ditempatkan di sekolah yang baru, mereka akan mempelajari sistem pendidikan di sekolah/daerah dan negara tersebut. Selanjutnya guru tersebut berkoordinasi dengan guru-guru lainnya untuk mencari serta berbagi 
pengalaman dalam pengelolaan dan pelaksanaan pendidikan di sekolah baru tempat bertugas.

Kunjungan tersebut memberikan kesempatan untuk mengembangkan jaringan dan hubungan profesional dengan kalangan pendidik yang berasal dari sekolah, daerah atau negara lain. Melalui kegiatan tersebut setahap demi setahap kualitas pendidikan, sesuai dengan visi dan misi sekolah untuk meningkatkan mutu pendidikan dapat diwujudkan. Peningkatan kualitas profesional guru dengan jalan pertukaran guru antar sekolah, darah atau negara memberikan kesempatan untuk mengalami secara langsung proses pendidikan yang terjadi di daerah lain yang telah maju.

Pada gilirannya hubungan baik antar sekolah, daerah atau negara dirasakan semakin menjadi suatu keharusan mengingat semakin tingginya tingkat ketergantungan antar sesama manusia. Melalui peralatan komunikasi, hubungan antar individu/masyarakat/negara semakin mudah dalam peningkatan kualitas pendidikan. Kemudahan ini pula yang menghantarkan berbagai informasi ke segala penjuru dunia dan menautkan berbagai budaya yang mempengaruhi berbagai aspek kehidupan guru dalam pelaksanaan proses belajar mengajar di sekolah.

\section{Penutup}

Guru yang profesional dituntut memiliki komitmen pada siswa dan proses belajarnya, menguasai secara mendalam bahan/mata pelajaran yang diajarkannya serta cara mengajarnya, bertanggung jawab memantau hasil 
belajar siswa melalui berbagai cara evaluasi, berfikir sistematis tentang apa yang dilakukannya dan belajar dari pengalamannya, serta bagian dari masyarakat belajar dalam lingkungan profesinya.

Pengembangan landasan pengetahuan guru dapat dilakukan dengan cara mengikuti program-program pendidikan dan pelatihan, studi lanjutan, atau program intensif. Pemerintah telah berupaya meningkatkan profesionalisme guru, diantaranya meningkatkan kualifikasi dan persyaratan jenjang pendidikan, serta program pertukaran guru antar sekolah, daerah dan negera tidak kalah penting dalam upaya peningkatan profesionalisasi.

Program pertukaran guru bermanfaat dalam memberikan latihan pengembangan profesi bagi guru, memperbaiki keterampilan berbahasa, memperkenalkan kepada mereka ide-ide yang membangkitkan semangat dan pengalaman hidup, serta mendorong hubungan secara pribadi maupun institusi. 


\section{Daftar Kepustakaan}

Akadum (1999) : Potret Guru Memasuki Milenium Ketiga. Suara Pembaharuan. (Online) (http://www.suara pembaharuan.com/News/1999/01/220199/OpEd, diakses 7 Juni 2001).

Arifin, I. (2000) : Profesionalisme Guru: Analisis Wacana Reformasi Pendidikan dalam Era Globalisasi. Simposium Nasional Pendidikan di Universitas Muham-madiyah Malang, 25-26 Juli 2001.

Dahrin, D (2000) : Memperbaiki Kinerja Pendidikan Nasional Secara Komprehensip: Transformasi Pendidikan. Komunitas, Forum Rektor Indonesia. Vol.1 No. Hlm 24.

Maister, DH (1997) : True Professionalism. New York: The Free Press.

Nasanius, Y (1998): Kemerosotan Pendidikan Kita: Guru dan Siswa Yang Berperan Besar, Bukan Kurikulum. Suara Pembaharuan. (Online) (http://www.suara pembaharuan.com/News/1998/08/230898, diakses 7 Juni 2001).

NRC. (1996) : Standar for Professional Development for Teacher Sains. Hlm. 5970

Pantiwati, Y. (2001) : Upaya Peningkatan Profesionalisme Guru Melalui Program Sertifikasi Guru Bidang Studi (untuk Guru MI dan MTs). Makalah Dipresentasikan. Malang: PSSJ PPS Universitas Malang. Hlm.1-12.

Semiawan, C.R ( 1991 : Mencari Strategi Pengembangan Pendidikan Nasional Menjelang Abad XXI. Jakarta: Grasindo.

Stiles, K.E. dan Loucks-Horsley, S. (1998) : Professional Development Strategies: Proffessional Learning Experiences Help Teachers Meet the Standards. The Science Teacher. September 1998. hlm. 46-49).

Sumargi. (1996) : Profesi Guru Antara Harapan dan Kenyataan. Suara Guru No. 3-4/1996. Hlm. 9-11.

Supriadi, D. (1998) : Mengangkat Citra dan Martabat Guru. Jakarta: Depdikbud.

Departemen Pendidikan Nasional. (2003): Undang-Undang Republik Indonesia Nomor 30 Tahun 2003. Jakarta : Depdiknas.

Tilaar, H.A.R. (1999): Profil Guru Indonesia Abad 21. Dalam Buku "Beberapa Agenda Reformasi Pendidikan Nasional Dalam Perspektif Abad 21". Magelang : Tera Indonesia. 


\section{PENINGKATAN PROFESIONALISASI}

MELALUI PERTUKARAN GURU

Oleh

Dr. Firman. MS

(Dosen Fakultas Ilmu Pendidikan Univ. Negeri Padang)

Disampaikan dalam Seminar Internasional Pendidikan dan Pertemuan FIP/JIP se Indonesia di Bukittinggi tanggal 12-14 September 2005

Fakultas Ilmu Pendidikan

Universitas Negeri Padang

2005 
